\title{
MJN EVALUATION OF STUDENT NURSES' USE OF THE INTERNET AND TECHNOLOGY IN EDUCATION AND SELF-EFFICACY PERCEPTIONS OF COMPUTER USE
}

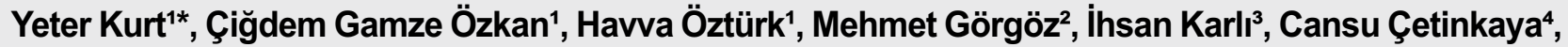 \\ Elif Kara ${ }^{5}$, Enes Aksu ${ }^{6}$, Kardem Birinci ${ }^{7}$
}

\author{
${ }^{1}$ Karadeniz Technical University, Faculty of Health Sciences, Department of Nursing, Trabzon, Turkey \\ ${ }^{2}$ Bayburt Public Hospital, Bayburt, Turkey \\ ${ }^{3}$ Hitit University Çorum Erol Olçok Training and Research Hospital, Çorum, Turkey \\ ${ }^{4}$ Zonguldak Atatürk Public Hospital, Zonguldak, Turkey \\ ${ }^{5}$ Kelkit Public Hospital, Turkey \\ ${ }^{6}$ Ağrı Public Hospital, Turkey \\ ${ }^{7}$ Kocaeli Darıca Farabi Training and Research Hospital, Turkey
}

*Corresponding Author's Email: ykurt6161@hotmail.com

\begin{abstract}
Background: In today's technology age, where information technology is rapidly improving, the ability to use technology and information effectively is among the competencies that a nurse should have. Objective: The research was carried out to determine student nurses' use of the internet, computer, and technology products in education and their self-efficacy perceptions about computer use. Methods: This descriptive research was carried out with 548 out of 786 student nurses. The data were collected with a questionnaire including students' demographic characteristics, use of computers and technology products, and a selfefficacy perception scale. Results: Students preferred their lessons about the nursing profession primarily in a laboratory environment (44\%), at hospitals $(24 \%)$, in a simulation center $(21 \%)$, and in a classroom environment (11\%). The students' mean self-efficacy perception score was found as $36.83 \pm 7.72$. In terms of using the computer in everyday life, self-efficacy perception scores of male students, fourth-grade students, those who preferred to have their lessons about the nursing profession in the simulation center, and those who often used mobile applications for educational purposes were found higher than those who were female, firstgrade students, those who wanted to have their lessons about the nursing profession in the laboratory, and those who used mobile applications only for several times respectively. Conclusion: The self-efficacy level of nursing students regarding computer use was slightly above the middle level, and the self-efficacy level of male and senior students was higher depending on the frequency of being more engaged in technology.
\end{abstract}

Keywords: Student Nurse, Nursing, Self-Efficacy, Technology, Computer

\section{INTRODUCTION}

The developments in science and technology, which cause significant changes in every area in today's world, have a great impact on the changing forms of accessing information and communication. The education system continues to evolve, depending on the rapid advances in technology, knowledge, and thus individuals. Technology has been an important component of education, especially with the proliferation of the internet, computers, and mobile devices (Billsberry \& Rollag, 2010; Friesen, 2012) In this context, the education of the new generation, born in the era of technology and interacting with technology in all areas of life, has become integrated with gradually increasing technology. Accordingly, when the relevant training was examined, it was seen that the training given through technological tools compared to the traditional methods enabled the students to listen to the lesson more actively 
and to grasp the subject in depth (Kenar, 2012) and enriched the learning environment, created a different educational environment, and increased the individual participation of the students (Kol, 2012).

\section{Background}

In higher education, educational technology, which helps students learn more meaningfully and efficiently by addressing many sensory organs in the learning process of the new generation (Metin et al., 2013), is an important element in facilitating teaching and learning (Jarosinski \& Heinrich, 2010; Rienties et al., 2013). It has also gained increasing importance in nursing education and has led many nurses to question the learning and teaching models of educators (Lombardi et al., 2013, Kisa \& Kaya, 2006). Technology offers nurse educators to constantly increase options that encourage lifelong learning, and also enables nurses and nursing students to learn, share information, and collaborate with colleagues around the world (Novotny \& Wyatt, 2006). On the other hand, it is observed that traditional methods, which are frequently used in nursing education today, are not sufficient to meet the changing needs and expectations of today's students, to increase and maintain their motivation (Prensky, 2001). Considering that students should acquire $21^{\text {st }}$ century prominent skills such as scientific, creative and critical thinking, problem-solving skills, taking responsibility for their learning, equal opportunities in teaching, cooperation, and communication (ISTE, 2018), it is an undeniable fact that technology should be integrated into nursing education. Innovative practices that can be an alternative to traditional learning environments in nursing education are expected to support effective, engaging, rapid and permanent learning and to meet changing student needs and expectations (Terzioğlu et al., 2012; Bromberg et al., 2013). Continuous change and development of technology bring along challenges as well as opportunities for nursing education. These challenges are the lack of in-service training, technical support, necessary hardware tools, and basic computer skills (Göktaş et al., 2013). The more nurse trainers use technology in education (Oermann et al., 2017) and the more they structure their educational environment (Fisher \& Newton, 2014), the more positive impact they will have on students' learning. Students' self-efficacy of technology use and computer literacy levels are very important for them to access and use many educational contents created by using computers in their educational processes. Accordingly, student nurses and educators must be trained to use technology effectively. Therefore, this study was carried out to evaluate student nurses' use of the internet, computer, and technology products in education and their self-efficacy perceptions about computer use.

\section{METHODOLOGY}

\section{Type and Purpose of the Study}

This study was carried out in a descriptive design to evaluate student nurses' use of the internet, computer, and technology products in education and their selfefficacy perceptions about computer use.

\section{The Universe and the Sample of the Research}

The universe of the study was composed of 786 nursing students studying at a university in Trabzon, and the sample included 548 (69.7\%) volunteer students.

\section{Ethical Considerations}

To conduct the research, necessary permission was obtained from the relevant institution (63582098/299/) on March 09, 2018, and all student nurses gave their informed consent before their inclusion in the study.

\section{Data Collection Tools and Process}

After obtaining consent from the volunteer students and permission from the relevant institution, the personal information form and the self-efficacy perception scale related to the computer use were distributed to the students by the researchers and collected between March 20 and April 14, 2018.

The Personal Information Form: The form was prepared by the researchers in line with the literature (Öztürk et al., 2018; Williamson \& Muckle, 2018; Karadağli \& Asl1, 2017; Hallila et al., 2014) consists of questions regarding the students' age, gender, marital status, the school they graduated from, and the use of computer technology products.

The Computer Self-Efficacy Scale (CSES): Based on Ișıksal \& Așkar (2003), the scale consists of 10 items in total. The five-point Likert-type scale is rated as '1Strongly Disagree, 2-Disagree, 3-Neutral, 4-Agree, and 5 -Strongly Agree'. The highest and the lowest scores on the scale are 50 and 10. Cronbach Alpha coefficients were found to be 0.86 in the study of Işıksal \& Aşkar (2003) and 0.84 in this study.

\section{DataAnalysis}

Number and percentage mean were used to define the 
demographic characteristics of the students. Kolmogorov -Smirnov tests were used to determine the status of the normal distribution of data. ANOVA, Kruskal Wallis test, t-test, Mann Whitney-U test was used when comparing the demographic characteristics and scale scores of the students. The results were evaluated at $95 \%$ confidence interval and a 5\% significance level.

\section{RESULTS}

It was found that the mean age of student nurses was $20.3 \pm 1.5,82.8 \%$ were female, and $97.3 \%$ were Turkish citizens. $75.2 \%$ of the students were super/Anatolian high school graduates, $29.9 \%$ were first-grade students, and $2.7 \%$ of them were citizens of foreign countries. Besides, the academic grade point average of the students was $3.2 \pm 0.4$.

The reasons for the use of internet by the students were investigated, and the following results were obtained; $82.1 \%$ of students used the internet to have fun (listening to music and playing games), $80.3 \%$ used it to do research, and $79.4 \%$ followed social networking sites. $91 \%$ and $49 \%$ of them used their mobile phones and computers for educational purposes, respectively. $58 \%$ often used mobile applications for educational purposes, while $44 \%$ preferred to take the courses related to the nursing profession primarily in a skill laboratory environment. About $92.7 \%$ stated that they wished to have lessons using new technological tools, $86.7 \%$ wished to follow the courses whenever and wherever they liked, and 53\% preferred to follow their courses on the internet (Table 1).

Table 1: Students' daily computer technology use and preferences $(N=548)$

\begin{tabular}{|l|c|c|}
\hline The Use of Computer Technology & N & \% \\
\hline $\begin{array}{l}\text { The use of mobile applications for educational } \\
\text { purposes }\end{array}$ & & \\
\hline $\begin{array}{l}\text { I have never used it for educational } \\
\text { purposes }\end{array}$ & 25 & 4.5 \\
\hline $\begin{array}{l}\text { I haveused it several times for educational } \\
\text { purposes }\end{array}$ & 208 & 38.0 \\
\hline I often use it for educational purposes & 315 & 57.5 \\
\hline Access tool used for educational purposes* & 496 & 90.5 \\
\hline Mobile phone & 266 & 48.5 \\
\hline Computer & 60 & 10.9 \\
\hline Tablet & & \\
\hline \multicolumn{2}{|l|}{} \\
\hline
\end{tabular}

\begin{tabular}{|l|c|l|}
\hline The reasons for the internet use * & & \\
\hline $\begin{array}{l}\text { Having fun (listening to music, playing } \\
\text { games) }\end{array}$ & 450 & 82.1 \\
\hline Doing research & 440 & 80.3 \\
\hline Following social networking site & 435 & 79.4 \\
\hline Doing homework & 336 & 61.3 \\
\hline Reading the news & 333 & 60.8 \\
\hline E-mailing & 215 & 39.2 \\
\hline Using it during the lesson & 198 & 36.1 \\
\hline Improving foreign language & 119 & 21.7 \\
\hline Writing & 100 & 18.2 \\
\hline Participating in competitions & 69 & 12.6 \\
\hline $\begin{array}{l}\text { Preferences regarding the learning environments } \\
\text { for nursing courses }\end{array}$ & \\
\hline \multicolumn{2}{|l|}{} \\
\hline Nursing Skill Laboratory & 240 & 43.8 \\
\hline Hospitals & 133 & 24.3 \\
\hline Simulation Center & 113 & 20.6 \\
\hline Class & 60 & 10.9 \\
\hline Others & 2 & 0.4 \\
\hline Preferences regarding the lessons * & 508 & 92.7 \\
\hline $\begin{array}{l}\text { Having lessons using new technological } \\
\text { tools }\end{array}$ & 291 & 53.1 \\
\hline Following lessons at any place and time & 475 & 86.7 \\
\hline Following the courses on the internet & 29 \\
\hline
\end{tabular}

${ }^{*}$ multiple marking.

Students showed $36.83 \pm 7.72$ in total from the Computer Self-Efficacy Scale (CSES). When the demographic characteristics and scale mean scores of the students were compared, it was seen that male students received higher scores than female students, and $4^{\text {th }}$ grade students had higher scores than 1st-grade students, which was statistically significant $(p<0.05)$. No statistically significant difference was found between scale scores in terms of the students' nationalities and the schools they graduated from $(p>0.05)$.

Comparing the students' descriptive features with their scale score averages, the students who used the internet for research, to improve their foreign language, to e-mail, to read the news and to participate in the competitions had statistically significantly higher scores on the scale than who did not $(p<0.05)$. The scale scores of the students who used the computer for educational purposes, often used mobile applications for educational purposes, who wished to have lessons about the nursing profession in the simulation centers, who wished to have lessons using new technological tools had higher scores than those who did not use the computer for educational purposes, who used mobile applications for educational purposes only for several times, who wished to have 
lessons about the nursing profession in the nursing skill laboratory, and who did not wish to have lessons using new technological tools, respectively $(p<0.05)$ (Table 2$)$.

Table 2: Comparison of Descriptive Characteristics of Students with Their Computer Self-Efficacy Scale Scores

\begin{tabular}{|c|c|c|}
\hline \multirow[t]{2}{*}{ Descriptive Characteristics } & \multicolumn{2}{|c|}{ Total Scale Score } \\
\hline & Mean \pm SD & Tests \\
\hline \multicolumn{3}{|l|}{ Gender } \\
\hline Female & $36.50 \pm 7.13$ & $t=2.218$ \\
\hline Male & $38.44 \pm 9.99$ & $p=0.018$ \\
\hline \multicolumn{3}{|l|}{ Grade } \\
\hline 1. Grade $a$ & $35.75 \pm 8.658$ & $F=2.657$ \\
\hline 2. Grade $b$ & $37.21 \pm 7.306$ & $P=0.048$ \\
\hline 3. Grade & $36.35 \pm 7.817$ & $\mathrm{~d}>\mathrm{a}(p<0.05)$ \\
\hline 4. $\mathrm{Grade}^{\mathrm{d}}$ & $38.06 \pm 6.706$ & \\
\hline \multicolumn{3}{|l|}{ Nationality } \\
\hline T.R. & $36.83 \pm 7.785$ & $\mathrm{U}=3845.500$ \\
\hline Foreign & $36.93 \pm 5.133$ & $P=0.801$ \\
\hline \multicolumn{3}{|l|}{ High school } \\
\hline $\begin{array}{l}\text { Vocational School of } \\
\text { Health } \\
\end{array}$ & $37.18 \pm 6.278$ & $\mathrm{KW}=4.792$ \\
\hline Normal High School & $35.18 \pm 7.928$ & $P=0.188$ \\
\hline $\begin{array}{l}\text { Super/Anatolian High } \\
\text { School }\end{array}$ & $37.05 \pm 7.711$ & \\
\hline Others & $38.40 \pm 8.287$ & \\
\hline \multicolumn{3}{|l|}{$\begin{array}{l}\text { Access tool used for educational } \\
\text { purposes * }\end{array}$} \\
\hline Mobile phone & $36.64 \pm 7.907$ & $\begin{array}{l}t=1.847 \\
p=0.065\end{array}$ \\
\hline Computer & $38.12 \pm 6.471$ & $\begin{array}{l}t=3.835 \\
p=0.000\end{array}$ \\
\hline Tablet & $37.37 \pm 7.109$ & $\begin{array}{l}t=0.566 ; \\
p=0.572\end{array}$ \\
\hline \multicolumn{3}{|l|}{$\begin{array}{l}\text { The use of mobile applications } \\
\text { for educational purposes }\end{array}$} \\
\hline $\begin{array}{l}\text { I have never used it for } \\
\text { educational purposes }{ }^{\text {e }}\end{array}$ & $36.32 \pm 7.680$ & $K W=16.401$ \\
\hline $\begin{array}{l}\text { I have used it several } \\
\text { times for educational } \\
\text { purposes }^{\mathrm{f}}\end{array}$ & $35.37 \pm 7.197$ & $P=0.000$ \\
\hline $\begin{array}{l}\text { I often use it for } \\
\text { educational purposes }{ }^{9}\end{array}$ & $37.84 \pm 7.920$ & $\mathbf{g}>\mathbf{f}$ \\
\hline \multicolumn{3}{|l|}{ The reasons for the internet use* } \\
\hline $\begin{array}{l}\text { Having fun (listening to } \\
\text { music, playing games) }\end{array}$ & $36.78 \pm 7.778$ & $\begin{array}{l}t=0.336 \\
p=0.737\end{array}$ \\
\hline Doing research & $37.26 \pm 7.216$ & $\begin{array}{l}t=2.644 \\
p=0.008\end{array}$ \\
\hline $\begin{array}{l}\text { Following social } \\
\text { networking site }\end{array}$ & $37.00 \pm 7.722$ & $\begin{array}{l}t=0.974 \\
p=0.330\end{array}$ \\
\hline Doing homework & $37.27 \pm 7.381$ & $\begin{array}{l}t=1.692 \\
p=0.093\end{array}$ \\
\hline
\end{tabular}

\begin{tabular}{|l|l|l|}
\hline Reading the news & $37.39 \pm 7.161$ & $\begin{array}{l}\boldsymbol{t}=\mathbf{3 . 5 8 1} \\
\boldsymbol{p}=\mathbf{0 . 0 0 0}\end{array}$ \\
\hline E-mailing & $38.29 \pm 6.596$ & $\begin{array}{l}\boldsymbol{t}=\mathbf{3 . 5 8 1} \\
\boldsymbol{p}=\mathbf{0 . 0 0 0}\end{array}$ \\
\hline Using it during the & $36.92 \pm 6.839$ & $\begin{array}{l}t=0.194 \\
p=0.846\end{array}$ \\
\hline lesson & & $\begin{array}{l}\boldsymbol{t} \mathbf{3 . 4 9 4} \\
\boldsymbol{p}=\mathbf{0 . 0 0 0}\end{array}$ \\
\hline Improving foreign & $39.00 \pm 7.233$ & $\begin{array}{l}t=313 \\
p=0.190\end{array}$ \\
\hline language & $37.75 \pm 6.895$ & $\begin{array}{l}\boldsymbol{t} \mathbf{2 . 0 8 2} \\
\boldsymbol{p}=\mathbf{0 . 0 3 8}\end{array}$ \\
\hline Writing & $38.64 \pm 8.368$ & \\
\hline Participating in & &
\end{tabular}

Preferences regarding the

learning environments

\begin{tabular}{|c|c|c|}
\hline $\begin{array}{l}\text { Nursing Skill } \\
\text { Laboratory }\end{array}$ & $35.73 \pm 7.626$ & \\
\hline 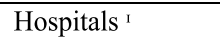 & $37.04 \pm 6.947$ & $F=3.708$ \\
\hline Simulation Center & $38.57 \pm 6.372$ & $p=0.012$ \\
\hline
\end{tabular}

Kruskal Wallis test

\section{DISCUSSION}

In today's world, where information technology is rapidly improving, the ability to use technology and information effectively is among the competencies that a nurse should have. In addition to these skills of future nurses, it is a necessity to improve, develop, and expand the computer use skills. In this context, computer use and computer self-efficacy have become indispensable skills for student nurses to use information effectively in today's technology age. For this reason, determining the computer self-efficacy status and planning appropriate initiatives for the needs during undergraduate education is going to contribute to the training of professional nurses to improve the quality of care in health care services.

In this context, students whose average age was 20 years old, who were mostly female, who were graduates of Super/Anatolian high schools, and whose academic grade average was 3, expressed that almost all of them used their mobile applications for educational purposes, and more than half of them often used mobile applications. However, it was also seen that most of the students used the internet to have fun, do research, and follow social networking sites. As seen, new generation ( $Z$ generation) student group, who was born and grew up in a technology-rich environment, spends most of their time with smart phones because internet technologies and digital hardware are defined as an indispensable part of daily life (Aldemir \& Akilli, 2015, Somyürek, 2014, Turner, 2015). These students, who constantly interact 
with video games, social networks, the internet, or 3D movies in their daily lives, think positively about computer-assisted teaching methods and thus provide positive feedback (Martín-Gutiérrez et al., 2015). According to TUIK's (2019) data, the rate of individuals having mobile phones/smart phones was $98.7 \%$, and the rate of using technologies such as TV, tablet/laptop and game console that can connect to the internet increased gradually. Mobile devices and mobile phones offer serious opportunities in terms of accessing, disseminating, and communicating information. The frequent use of mobile devices and mobile phones also changes the way we live and access education (Franklin \& Peng, 2008). Various studies have reported that most of the students prefer mobile learning and mobile technologies in their education (Abu-Al-Aish \& Love, 2013; Kıc1, 2010), and they use mobile devices and smart phones to access information, share and access the course materials (Seliaman \& Al-Turki, 2012). Also, mobile devices improve learners' ability to use and share information, access information, and problem-solving skills which positively affect their learning motivations (Chen et al., 2008, Özsarı \& Sayk111, 2020). The fact that mobile technologies provide users with "anytime and anywhere" learning opportunity enables these applications to be applied more frequently in learning environments (Stockwell, 2008). The differentiation of the student profile and the expected outcomes from education also requires the achievement of training with technological methods and the integration of technology into education. In the study of Williamson et al. (2018), almost all of the student nurses stated that the use of technology in training would be beneficial and increase their performance. In parallel with the literature, the results of this study also showed that it is important for student nurses to use computers and similar technologies more effectively and efficiently in their education.

Considering that nurses use health technology very frequently, it is seen that computer technology has a very significant place in care practices because nurses who make evidence-based decisions for professional health care enhance the quality of patient care and reduce the cost by using information/health technologies (Kaya et al., 2008). Therefore, student nurses must use this knowledge and skills very well and be sufficient in this regard. It is an undeniable fact that the need for training of nurses who can make evidence-based decisions using information technologies for professional health care is required. To achieve this goal, first of all, the integration of computer-based technologies into the nursing education system should be carried out, the student nurses' perceptions about the use of technology should be determined, and their acceptance of technology use in nursing practices should be evaluated (Holden \& Karsh, 2010) because it is reported that computer self-efficacy has a positive relationship with learning performance (Chen, 2017).

In this study, the evaluation of students' computer self-efficacy perceptions showed that the scale total score of the students was slightly higher than the middle level. In other words, students' perceptions of computer selfefficacy are positive. Öztürk et al. (2018) determined that nursing students' perceptions of computer self-efficacy were moderate and found themselves sufficient. As a result of the studies carried out in nursing schools providing education with computer and computer networks in many countries of the world, it has been observed that nursing students exhibit positive attitudes towards the use of technology (Raman, 2015; StrandellLaine et al., 2015; Warshawski et al., 2019). Atay et al. (2014) also suggested that nursing students had positive attitudes towards computer use in health services. In this study, student nurses' positive computer self-efficacy perceptions may enable them to actively use computersupported care systems and increase the number of more professional nurses in healthcare.

The expected outcome for generation $\mathrm{Z}$, which can use internet technologies and digital hardware as they wish and defines this hardware as an indispensable part of daily life, is to have good self-efficacy perceptions about computer use (Aldemir \& Akilli, 2015; Somyürek, 2014; Turner, 2015). However, in the evaluation of this study in light of this information, it is noteworthy that student nurses' perceptions of computer self-efficacy are not as high as desired. The reason for this may is the inability to fully integrate information technologies into nursing and nursing education, insufficient computer literacy, students' lack of thinking of good computer use as a necessity, their resistance to change, and limited resources such as technological equipment for education.

Self-efficacy studies carried out since the process of providing computer technology education in schools have shown that the competencies of male students are higher than female students (Cooper, 2006). Likewise, in this study, the computer self-efficacy of male students was found higher than female students. Male students showed a more positive attitude towards computers compared to female students (OECD, 2011, Fraillon et al., 2014). 
During nursing education, students have used technological tools many times for research and information within the scope of courses. In this study, self-efficacy scores of fourth-grade students were found higher than first-grade students. This finding was similar to studies reported by Tatli et al., (2018) and Williamson et al., (2018). This may be because firstgrade students' lessons are mostly given by nurse educators, or that the number of assignments that first graders usually prepare via computer and internet is fewer than other grades. Some students may be preparing an assignment for the first-time using computer programs because nursing students' families have generally moderate socioeconomic status (Özturk et al., 2020). Since some of the students do not have a computer or android mobile phone, self-efficacy perception levels may be affected. The high level of selfefficacy perception of fourth-grade students may be due to the university's opportunities offered to the students, their ability to use them during the education process, and preparing many nursing courses and clinical practice assignments via computer or internet in the final year.

Computer self-efficacy scores were determined higher in students who often used mobile applications for educational purposes than the others. This situation may have resulted from the fact that their frequent use of computers increased their competence or their preference to use mobile and computer-based technologies frequently developed their related skills. Tatli et al. (2018) also reported that the majority of student nurses preferred both smart phone and a computer to access information.

In this study, the self-efficacy perceptions of students using the internet to do research, develop a foreign language, e-mail, read the news, and participate in competitions were found to be high. This finding is supported by other research results in the literature. For example, 89\% of students who attended ICILS 2013 stated that they could use the internet to search and find information (Fraillon et al., 2014). Yardimc1 et al. (2019) indicated that individuals used the internet because of social media usage, research, and game-play habits. In line with these results, it can be said that the students who use technological tools have a higher level of computer self-efficacy and that their self-efficacy level is more advanced or expected to be more sufficient.

In this study, the students who wished to take their professional courses in the simulation center rather than the laboratory were found to have higher computer selfefficacy perceptions. Besides, almost all of the students preferred to have their education/lessons using new using new technological tools. In other words, students wishing to use technological tools in their education and feeling sufficient in using computers want to have education in technologically equipped simulation centers. Parallel to this study, in the study of Terzioğlu et al. (2012), students stated that it would be beneficial to replace the mannequins used in skill practices given in the laboratory and classroom to feel more competent with more developed and responsive mannequins. The use of a simulation technique, which is one of the innovative teaching methods and interactive methods and also an important educational strategy in laboratories, which is the first step in skill acquisition (Robinson \& Dearmon, 2013; Durmaz Edeer \& Dicle, 2015; Bland et al., 2011). Simulation, which is a technique that provides a real experience of a real environment under the guidance of a supervisor, enables students to act as if they were in a real situation (Gaba, 2007). Within this scope, this preference may arise from the students' awareness of the effectiveness of the simulation method, and the fact that they feel more adequate in this regard, or the instructors can guide the students in a way to support the simulation practices in the lessons. Therefore, these results show that simulation applications should be used more frequently in nursing education.

\section{Limitations of the Research}

That the research is conducted only with the views of the student nurses studying at a university is the limitation of the research.

\section{CONCLUSION}

Thanks to the widespread use of the internet, computers, and mobile devices, major developments in information production have differentiated the student profile and the outcomes expected from education. In this context, nursing students should have sufficient skills in using computers and technology for academic and professional purposes.

This study, in which student nurses' preferences and computer self-efficacy regarding the use of technology in education was investigated, revealed that the selfefficacy level of nursing students regarding computer use was slightly above the middle level, and the self-efficacy level of male and senior students was higher depending on the frequency of being more engaged in technology. The frequent use of technology and increased awareness, 
students who desired to follow lessons in the simulation center of the lessons and who used mobile applications frequently for educational purposes had higher selfefficacy perceptions. Additionally, students who used the internet to do research, to improve their foreign language skills, to send e-mails, to read the news, and to participate in competitions were found to have higher self-efficacy perceptions depending on the willingness to use and discover the internet. In line with these results, it was concluded that considering the preferences of the students, new technology should be integrated into nursing education for the learning success of these students in the $\mathrm{Z}$ generation. Nurse educators, who have an important role in training new generation nurses, should also understand the learning needs of this group and encourage them to learn by facilitating their interests and abilities. For this purpose, technological tools should be used to increase the students' experience of using computers, or instead of traditional teaching instruments educators should use technology-based tools, methods and various activities that enable students to use of technology. Thus, nurses who are knowledgeable, experienced, and confident about computer use can be trained. As a result, in the age of rapidly changing and growing information and technology, lifelong learning nurses can take part in health institutions. Thus, the competence of newly trained nurses in their professions can be improved by integrating their knowledge, skills, and critical thinking skills regarding information technologies into the nursing profession.

\section{Conflict of Interests}

The authors declare that they have no conflict of interest.

\section{ACKNOWLEDGEMENTS}

The authors would like to thank the nursing students who participated in this study for their time and patience.

\section{REFERENCES}

Abu-Al-Aish, A. \& Love, S. (2013). Factors influencing students' acceptance of m-learning: An investigation in higher education. International Review of Research in Open and Distributed Learning, 14(5), pp 82-107.

Aldemir, T. \& Akilli, G.K. (2015). Student' Opinions and Perceptions about a Gamified Online Course: A Qualitative Study. $38^{\text {th }}$ Annual Proceedings, Indianapolis, 1, pp 1-11.

Atay, S., Arıkan, D., Yılmaz, F., Aslantürk, N. \& Uzun, A. (2014). Nursing and midwifery students' attitudes to computer use in healthcare. Nursing Practice Today, 1(3), pp 147-154.

Billsberry, J. \& Rollag, K. (2010). New technological advances applied to management education. Journal of Management Education, 34(5), pp 777-779.

Bland, A.J., Topping, A. \& Wood, B. (2011). A concept analysis of simulation as a learning strategy in the education of undergraduate nursing students. Nurse Education Today, 31(7), pp 664-670.

Bromberg, N.R., Techatassanasoontorn, A.A. \& Andrade, A.D. (2013). Engaging students: Digital storytelling in information systems learning. Asia Pacific Journal of the Association for Information Systems, 5(1), pp 1-22.

Chen, G.D., Chang, C.K. \& Wang, C.Y. (2008). Ubiquitous learning website: Scaffold learners by mobile devices with information-aware techniques. Computers \& Education, 50(1), pp 77-90.

Chen, I.S. (2017). Computer self-efficacy, learning performance, and the mediating role of learning engagement. Computers in Human Behavior, 72, pp 362-370.

Cooper, J. (2006). The digital divide: The special case of gender. Journal of Computer Assisted Learning, 22(5), pp 320-334.

Durmaz Edeer, A. \& Dicle, A. (2015). Hemşirelik eğitiminde simülasyon kullanımı ve simülasyon tipleri. Koç Üniversitesi Hemşirelikte Eğitim ve Araştırma Dergisi, 12(2), pp 121-125.

Fisher, K. \& Newton, C. (2014). Transforming the twenty-first-century campus to enhance the net-generation student 
learning experience: Using evidence-based design to determine what works and why in virtual/physical teaching spaces. Higher Education Research \& Development, 33(5), pp 903-920.

Fraillon, J., Ainley, J., Schulz, W., Friedman, T. \& Gebhardt, E. (2014). Preparing for life in a digital age: The IEA international computer and information literacy study international report. Springer International Publishing, Heidelberg, New York, Dordrecht, London.

Franklin, T. \& Peng, L. W. (2008). Mobile math: Math educators and students engage in mobile learning. Journal of Computing in Higher Education, 20(2), pp 69-80.

Friesen, N. (2012). Report: Defining Blended Learning. Retrived from: http://learningspaces. org/papers. Defining_Blended_Learning_NF.Pdf.

Gaba, D.M. (2007). The future vision of simulation in healthcare. Simulation in Healthcare, 2(2), pp 126-135.

Göktas, Y., Gedik, N. \& Baydaş, O. (2013). Enablers and barriers to the use of ICT in primary schools in Turkey: A comparative study of 2005-2011. Computers \& Education, 68, pp 211-222.

Hallila, L. E., Al Zubaidi, R., Al Ghamdi, N. \& Alexander, G. (2014). Nursing students' use of internet and computer for their education in the college of nursing. International Journal of Nursing \& Clinical Practices, 1, pp 1-5.

Holden, R.J. \& Karsh, B. T. (2010). The technology acceptance model: its past and its future in health care. Journal of Biomedical Informatics, 43(1), pp 159-172.

ISTE. (2018). The National Educational Technology Standards for students. Retrieved from: https://www. iste.org/standards/for-students.

Işıksal, M. \& Așkar, P. (2003). İlköğretim öğrencileri için matematik ve bilgisayar öz-yeterlik algısı ölçekleri. Hacettepe Üniversitesi Eğitim Fakültesi Dergisi, 25(25), pp 109-118.

Jarosinski, J. M. \& Heinrich, C. (2010). Standing in their shoes: Student immersion in the community using servicelearning with at-risk teens. Issues in Mental Health Nursing, 31(4), pp 288-297.

Karadağl1, F. \& Genç, G. (2017). Hemşirelik öğrencilerinin hemşirelik uygulamalarında bilgisayar kullanımına ilişkin görüşlerinin belirlenmesi. İstanbul Gelişim Üniversitesi Sağlık Bilimleri Dergisi, 3, pp 260-274.

Kaya, N., Aşt1, T., Kaya, H. \& Kaçar, G. Y. (2008). Hemşirelerin bilgisayar kullanımına ilişkin görüşlerinin belirlenmesi. Florence Nightingale Hemşirelik Dergisi, 16(62), pp 83-89.

Kenar, İ. (2012). Teknoloji ve derslerde teknoloji kullanımına yönelik veli tutum ölçeği geliştirilmesi ve tablet PC uygulaması. Eğitim Bilimleri Araştırmaları Dergisi, 2(2), pp 123-139.

Kıc1, D. (2010). Üniversite öğrencilerinin mobil öğrenmenin üniversite eğitimindeki etkisi konusundaki beklentileri üzerine bir araştırma. International Conference on New Trends in Education and their Implications, Antalya.

Kısa, B. \& Kaya, H. (2006). Hemşire öğretim elemanlarının teknolojiye ilişkin tutumları. The Turkish Journal of Educational Technology-TOJET, 5 (2) pp 77-83.

Kol, S. (2012). Okul öncesi eğitimde teknolojik araç-gereç kullanımına yönelik tutum ölçeği geliştirilmesi. Kastamonu Eğitim Dergisi, 20(2), pp 543-554.

Lombardi, M. M., Sutphen, M. \& Day, L. (2013). Educating nurses the call for transformation of nursing education. In K. H..Frith and D. J. Clark (Eds), Distance Education in Nursing, $2^{\text {nd }}$ Edition, Springer Publishing Company, New York.

Martín-Gutiérrez, J., Fabiani, P., Benesova, W., Meneses, M. D. \& Mora, C. E. (2015). Augmented reality to promote collaborative and autonomous learning in higher education. Computers in Human Behavior, 51, pp 752-761.

Metin, M., Birişçi, S. \& Coşkun, K. (2013). Öğretmen adaylarının öğretim teknolojilerine yönelik tutumlarının farklı 
değişkenler açısından incelenmesi. Kastamonu Ĕ̆itim Dergisi, 21(4), pp 1345-1364.

Novotny, J.M. \& Wyatt, T.H. (2006). An overview of distance education and web-based courses. In K. H..Frith and D. J. Clark(Eds), Distance Education in Nursing, $2^{\text {nd }}$ Edition, Springer Publishing Company, New York.

OECD (2011). PISA 2009 Results: Students On Line: Digital Technologies and Performance (Volume VI). OECD Publishing, Paris, France.

Oermann, M. H., Shellenbarger, T. \& Gaberson, K. (2017). Clinical Teaching Strategies In Nursing. Springer Publishing Company, New York.

Özsar1, G. \& Sayk11, A. (2020). Mobile learning in Turkey: Trends, potentials and challenges. Journal of Educational Technology and Online Learning, 3(1), pp 108-132.

Öztürk, H., Bayram, S.B., Bayrak, B., Aydın, M., Özkan, Ç.G., Kurt, Y. \& Kılınc, K.Ö. (2020). The Effect of one-to-one education on nursing student's realizing and repeating practices. International Journal of Caring Sciences, 13(1), pp 241-251.

Öztürk A., Tezel A., Bora C. \& Arslan N. (2018). Hemşirelik öğrencilerinin bilgisayar öz-yeterlik algılarının değerlendirilmesi. Anadolu Hemşirelikve Sağllk Bilimleri Dergisi, 21(4), 249-255.

Prensky, M. (2001). Digital natives, digital immigrants. On the horizon, MCB University Press, 9(5).

Raman, J. (2015). Mobile technology in nursing education: where do we go from here? A review of the literature. Nurse Education Today, 35(5), pp 663-672.

Rienties, B., Brouwer, N. \& Lygo-Baker, S. (2013). The effects of online professional development on higher education teachers' beliefs and intentions towards learning facilitation and technology. Teaching and Teacher Education, 29, pp 122-131.

Robinson, B. K. \& Dearmon, V. (2013). Evidence-based nursing education: Effective use of instructional design and simulated learning environments to enhance knowledge transfer in undergraduate nursing students. Journal of Professional Nursing, 29(4), pp 203-209.

Seliaman, M. E. \& Al-Turki, M. S. (2012). Mobile learning adoption in Saudi Arabia. World Academy of Science, Engineering and Technology, 69(9), pp 391-293.

Somyürek, S. (2014). Öğretim sürecinde Z kuşağının dikkatini çekme: artırılmış gerçeklik. Eğitim Teknolojisi Kuram ve Uygulama, 4(1), pp 63-80.

Stockwell, G. (2008). Investigating learner preparedness for and usage patterns of mobile learning. ReCALL: Journal of EUROCALL, 20(3), pp 253-270.

Strandell-Laine, C., Stolt, M., Leino-Kilpi, H. \& Saarikoski, M. (2015). Use of mobile devices in nursing student-nurse teacher cooperation during the clinical practicum: An integrative review. Nurse Education Today, 35(3), pp 493499.

Tatl1,Z., Aydın, A., Şimşek, P., Özdemir, M., Gölbaşı, S., Karacan, S., Gürsoy, A. \& Gündüz, A. (2018). Hemşirelerin ve hemşirelik öğrencilerinin bilişim teknolojilerini kullanma durumları. Ordu Üniversitesi Hemşirelik Çalışmaları Dergisi, 1(1), pp 18-27.

Terzioğlu, F., Kapucu, S., Özdemir, L., Boztepe, H., Duygulu, S., TunA, Z. \& Akdemir, N. (2012). Simülasyon yöntemine ilişkin hemşirelik öğrencilerinin görüşleri. Hacettepe Üniversitesi Hemşirelik Fakültesi Dergisi, 19, pp $16-23$.

TUİK. (2019). Hanehalkı Bilişim Teknolojileri Kullanım Araştırması. Retrived from: https://dijilopedi.com/2019tuik-hanehalki-bilisim-teknolojileri-kullanim-arastirmasi/. 
Turner, A. (2015). Generation Z: Technology and social interest. The Journal of Individual Psychology, 71(2), pp 103113.

Warshawski, S., Itzhaki, M. \& Barnoy, S. (2019). Nurse and nurse student attitudes and perceived self-efficacy in use of information and communication technologies: professional and cultural differences. CIN: Computers, Informatics, Nursing, 37(1), pp 20-28.

Williamson, K. M. \& Muckle, J. (2018). Students' perception of technology use in nursing education. CIN: Computers, Informatics, Nursing, 36(2), pp 70-76.

Yardımcı, İ., Özgeldi, M. \& ve Akan, G. (2019). Üniversite öğrencilerinin dijitalleşmeye ilişkin görüşlerinin incelenmesine yönelik bir araştırma. Proceedings of the International Congress on Business and Marketing, pp 418-430. 